\title{
Aeromycoflora in Outdoor Environment of Timisoara City (Romania)
}

\author{
Nicoleta IANOVICI, Dorina TUDORICA \\ West University of Timisoara, Department of Biology, Faculty of Chemistry-Biology-Geography, Romania; nicole_ianovici@yahoo.com
}

\begin{abstract}
An aeromycological study to identify and quantify allergenic fungi and their fluctuations was conducted at Timisoara. The diversity of the aeromycoflora in this study, based on the recovery of fungal propagules by the volumetric sampling method was conducted for 30 days using the Lanzoni sampler. The study showed that the most prevalent (major components) fungal spores in the air of Timisoara were Cladosporium spp., Drechslera/Helminthosporium spp., Alternaria spp. and Epicoccum spp. The abundant genera were Cladosporium, Fusarium/Leptosphaeria, Drechslera/Helminthosporium, Alternaria and Torula. Cladosporium was the most abundant fungal spore type (41\%) collected throughout the period of study reaching.
\end{abstract}

Keywords: aeromycoflora, allergenic fungi, Cladosporium

\section{Introduction}

Airborne fungi are considered to act as indicator of the level of atmospheric bio-pollution. The presence of fungal propagules, volatiles and mycotoxins in the air can cause a health hazard in all segments of the population (Kakde et al., 2001). Airborne fungal spores are ubiquitous in nature (Burge, 1985). Much of our knowledge on the behaviour of airborne spores comes from various studies on the epidemiology of plants, animals and human diseases, especially infections of the respiratory tract and allergy (Comtois, 1990; Angulo-Romero et al., 1996). More than 80 genera of fungi have been associated with respiratory tract allergy (Karlsson-Borga et al., 1989; Horner et al., 1995). Most of the allergenic fungi are classified under Ascomycetes and Deuteromycetes with a few in Basidiomycetes (Kurup et al., 2000). Some genera of airborne fungal spores such as Alternaria, Aspergillus, and Cladosporium are found throughout the world (Vijay et al., 1999). Disease expression is affected by the degree of exposure. Repeated exposures to large concentrations of spores, mostly $1-5 \mu \mathrm{m}$ in diameter, may cause severe symptoms of respiratory allergy (Barui Chandra and Chanda, 2000). Even though mould spores are present in the air in concentrations considerably greater than pollen grains, the frequency of allergic respiratory diseases due to moulds is usually much lower than pollen grains of vascular plants (D'Amato and Spieksma, 1995). The prevalence of respiratory allergy to fungi is estimated at 20 to $30 \%$ among atopic individuals and up to $6 \%$ in general population (Wuethrich, 1989). It is of the most importance that allergens, viable microbes, and other noxious agents that prevail in any particular environment, or are induced by changes in meteorologic conditions, be identified and studied. These measures will not only help to monitor the levels of these agents in the environment but also aid clinicians in advising and treating patients as well as those at risk before they are exposed and sensitized (Zwick et al., 1991).

Very little was reported on the impact of airborne fungi on monuments and rock surfaces in indoor and outdoor environments (Mandrioli and Zenotti Censoni, 1982; Urzi et al., 2001). Most of the researches have dealt with fungi already settled on the rock surface and/or with "autochtonous mycoflora” (Saiz-Jimenez, 1995). Fungal airspora are implicated in the damage of food commodities and in the deterioration of organic materials and stored products (Pyrri and Kapsanaki-Gotsi, 2007).

Airborne fungi occur as single units, spores and occasionally as hyphal fragments, conidiophores, associated with inorganic particles or as "bioaerosol" (Comtois, 1990). Number and type of fungi vary with time of day, weather and seasonal fluctuation, condition of the surrounding areas, climatic conditions and with the presence of a local source of spores (Pepeljnjak and Šegvić Klarić, 2003). The presence of plants, known to produce essential oils and aerosol, which showed sporistatic, fungistatic, and fungicidal activities (Pepeljnjak and Šegvić Klarić, 2003), possibly reduces airspora viability. Increase of $\mathrm{CO}_{2}$ concentration stimulates fungal sporulation suggesting that levels of the airspora correlate with air pollution (Klironomos et al., 1997). In addition, increase of $\mathrm{SO}_{2}$ can reduce airborne fungi concentration (Asan et al., 2002).

The distribution of airborne fungi in Europe may differ from that in North America and Japan because of differences in climate, vegetation, and the structure of houses (Takahashi, 1997). Only a few studies have been carried out in Romania on airborne fungi. Ianovici and Faur (2003) used a volumetric method for the first time in a Romania study during their investigation of airborne fungi in the city of Timisoara. The examination of common 
22

airborne fungi distribution in a particular region can be helpful in: identifying association between fungal sensitisation and clinical diagnosis; and clinical prevention of the seasonal allergic diseases (Wu et al., 2000).Therefore, the purpose of our study was to determine variations in the composition and concentration of the aeromycoflora in Timisoara.

\section{Materials and methods}

\section{Spore sampling and identification}

Concentrations of airborne fungal spores were measured from 1 July to 31 July, 2007 using 7-day recording volumetric spore trap. The sampler was situated on the Tab. 1. Monthly mean temperatures and monthly mean precip

\begin{tabular}{cccccccccccccc} 
Tab. 1. Monthly mean temperatures and monthly mean precipitations in Timisoara compared to multi-annual means \\
\hline & I & II & III & IV & V & VI & VII & VIII & IX & X & XI & XII \\
\hline Monthly mean temperatures 2007 & 4 & 6 & 9 & 13 & 18 & 23 & 24 & 23 & 12 & 11 & 4,2 & 0,1 \\
\hline Multi-annual means & $-1,2$ & 0,4 & 6 & 11 & 17 & 20 & 22 & 21 & 17 & 11 & 5,7 & 1,4 \\
Monthly mean precipitations 2007 & 26 & 92 & 57 & 4 & 69 & 65 & 46 & 65 & 62 & 53 & 86 & 23 \\
Multi-annual means & 41 & 40 & 42 & 50 & 67 & 81 & 60 & 52 & 46 & 55 & 49 & 48 \\
\hline
\end{tabular}

roof of the West University building in the centre of the city. The sampling site is above the adjacent buildings, and the circulation of the air currents was unobstructed in all directions. The flow rates were adjusted to $10 / \mathrm{min}$ and checked weekly. At sampling site, tape were changed weekly at 13.00 hours (local time). The tapes were cut into strips $48 \mathrm{~mm}$ long, each representing $24 \mathrm{~h}$ exposure, and were mounted on microscope slides in gelatin-glycerin and stained with basic fuchsin. Spores were counted in five fields along traverses $4 \mathrm{~mm}$ apart, using an optical microscope at $\times 400$ magnification. Traverses represented the deposits collected in alternate hours. The counts were used to calculate both daily and hourly mean concentrations of spores $/ \mathrm{m}^{3}$. Fungal spores were classified by appearance and morphological characteristics (colour, size and shape) and identified, where possible, by comparison with published keys and monographs (Smith, 1990). Fungal identification on the basis of their morphological characteristics is difficult and inaccurate in many cases because almost identical and indistinct spores can exist within a family. In most cases it is possible to identify only to the genus level, sometimes even this level is unidentifiable. For that reason we use the term "type" to include different genera whose spores are morphologically very similar. Distinguishing the conidia of Bipolaris Shoemaker 1959, Drechslera S. Ito 1930, Exserohilum K.J. Leonard and Suggs 1974, Sporidesmium Link 1809, Helminthosporium Link 1809 using an optic microscope is extremely difficult; they were therefore considered as belonging to the Drechslera/Helminthosporium type (are listed as the Drech/Helminth). The Fusarium/Leptosphaeria group type included spores of Melanomma Nitschke ex Fuckel 1870 and Phaeosphaeria I. Miyake 1909. The genera Aspergillus and Penicillium are indistinguishable by their conidia and are listed as the
Asp-Pen type. The broken hyphae or conidiophores were recorded as hyphal fragments.

\section{Sampling site}

The climate that defines Timisoara city is the moderate temperate-continental climate sector in the plain areas, where there is interference of western and tropical circulations. It is characterised by frequent advections of maritime air and of tropical air laden with moisture: as a result, annual average temperature is below $11^{\circ} \mathrm{C}$ and rainfall amounts reach $600 \mathrm{~mm}$ (Mircov et al., 2007). The meteorological data for Timisoara were obtained from the records of the Meteorological Station (after David et al., 2008). Ths weather in Timisoara in July 2007 was

dry (Tab. 1). The July 2007 was characterised by deficient amount compared to multi-annual average. The warmest month during this period was July with an average temperature of $24^{\circ} \mathrm{C}$.

\section{Results and discussion}

The occurrence of aeromycoflora in outdoor and indoor environments as well as the fluctuations in their numbers and composition is receiving increasingly attention within the framework of potential health hazards to both flora and fauna, including humans. Fungal spores that are transported by air currents cause many plant diseases, and a knowledge of their periodicity is of great value in terms of predicting plant epidemics. Airborne fungi have also been implicated as the causal factor in various human diseases and as elicitors of allergic and/or toxic responses. Great concern has been expressed about potential health hazards to humans, with a special focus on allergenic or toxigenic fungi and their association with air quality (Horner $e t$ al., 1995).

The objectives of the present study are to record the airborne fungi in an urban environment during the dry season using modern aerobiological sampling technique. Measurements were made in July of 2007 because most reports showed that higher concentrations of airborne fungi were recorded during the summer.

32 fungi in outdoor air in the present study is reported. The airborne fungal genera are listed in Table 2 in descending order based on their frequencies, which were calculated as positive samples in the total number of samples. Airborne fungi were grouped into "major" and "minor" components depending upon their frequency of appearance and catch percentage in the air. Cladosporium spp., 
Drechslera/Helminthosporium spp., Alternaria spp. and Epicoccum spp. were included as major components. Minor components included 8 airborne fungal genera. Major components included most frequently encountered genera such as Cladosporium while minor components included less frequent and sporadic types.

Cladosporium, Alternaria, Epicoccum and Drechsleral Helminthosporium type spores were trapped most frequently ( $100 \%$ of days). Other stable components of aeromycota were Peronospora, Aspergillus/Penicillium, Xilaria, Torula and Pithomyces (>70\%). Helicoma, Ascobolus, Amphisphaeria, Asterosporium, Capronia, Kassariosphaeria, Massariosphaeria and Curvularia were rare in samples, found only one or three times during sampling. These results are comparable to those from a previous study. Amongst the fungal spores group, Acrodictys, Cercospora, Chaetosphaerella, Chaetoconis, Cerebella, Comoclathris, Fusariella, Lewia,

Tab. 2. Frequency and abundance of airborne fungi detected in Timisoara

\begin{tabular}{|c|c|c|}
\hline Airborne fungi & $\begin{array}{l}\text { Frequency } \\
\text { (\% of days) }\end{array}$ & $\begin{array}{c}\text { Abundance } \\
\text { (\% of total spores) }\end{array}$ \\
\hline Alternaria & 100 & 7 \\
\hline Cladosporium & 100 & 41 \\
\hline Drech/Helminth type & 100 & 8 \\
\hline Epicoccum & 100 & 4 \\
\hline Asp-Pen type & 93.33 & 5.81 \\
\hline Peronospora & 93.33 & 3 \\
\hline Xilaria & 90 & 5 \\
\hline Torula & 83.33 & 6 \\
\hline Pithomyces & 80 & 0.1 \\
\hline Spondylocladiella & 73.33 & 0.02 \\
\hline Periconia & 73.33 & 1.1 \\
\hline Stemphylium & 70 & 1 \\
\hline Tilletia & 63.33 & 1 \\
\hline Piricauda & 60 & 1 \\
\hline Massarina & 53.33 & 1 \\
\hline Bispora & 40 & 0.3 \\
\hline Microsporum & 40 & 0.3 \\
\hline Nigrospora & 36.66 & 0.2 \\
\hline Pseudocercospora & 36.66 & 2 \\
\hline Paraphaeosphaeria & 33.33 & 1.1 \\
\hline Neohendersonia & 30 & 0.2 \\
\hline Monodictys & 23.33 & 0.1 \\
\hline Oidium & 23.33 & 0.3 \\
\hline Helicoma & 20 & 0.2 \\
\hline Ascobolus & 16.6 & 2 \\
\hline $\begin{array}{l}\text { Fusarium/ } \\
\text { Leptosphaeria type }\end{array}$ & 8.33 & 8 \\
\hline Amphisphaeria & 6.66 & 0.02 \\
\hline Asterosporium & 6.66 & 0.01 \\
\hline Capronia & 6.66 & 0.1 \\
\hline Kassariosphaeria & 6.66 & 0.1 \\
\hline Massariosphaeria & 6.66 & 0.03 \\
\hline Curvularia & 3.33 & 0.01 \\
\hline
\end{tabular}

Lophiostoma, Splanchnonema and Puccinia constituted the sporadic types in the airspora for 2005 (Ianovici et al., 2007). In 2006 other fungal spore types were identified in air samples such as Agrocybe, Asperisporium, Botrytis, Caloplaca, Ceratosporium, Cercosporella, Chaetomium, Comoclathris, Delitschia, Dendryphiella, Diatrype, Diplodia, Farlowiella, Fusichalara, Fusicladium, Ganoderma, Massaria, Mytilidion, Pestalotiopsis, Polythrincium, Sordaria, Sporormiella, Stachybotrys, Trichodelitschia, Ulocladium, Uromyces (Ianovici, 2008).

Cladosporium (7104.1 spores $\left./ \mathrm{m}^{3}\right)$, Drechslera/Helminthosporium (1378.7 spores/ $\mathrm{m}^{3}$ ), Fusarium/Leptosphaeria $\left(1378.7\right.$ spores $\left./ \mathrm{m}^{3}\right)$, Alternaria $\left(1212.1\right.$ spores $/ \mathrm{m}^{3}$ ) and Torula $\left(1051.3\right.$ spores $\left./ \mathrm{m}^{3}\right)$ type spores were trapped in greatest abundance ( $>6 \%$ of total). These represent a group of taxa of cosmopolitan fungi that can exploit virtually any organic substrate (Ianovici, 2008).

The genus Cladosporium predominated and it is the most important genus in terms of defining variations in the total count. In July 2007, the air concentration of $\mathrm{Cla}$ dosporium spores did not exceed the level of 3000 spores/ $\mathrm{m}^{3}$ (potential to trigger allergic reactions). This genus is also the major constituent in outdoor air and presents similar fluctuations in other European temperate regions (Infante et al., 1999b; Stepalska et al., 1999; Filipello Marchisio and Airaudi, 2001).

The genus Alternaria is also a major constituent of the fungal bioaerosol. Only one day ( 1 July) the concentration of Alternaria exceed the 100 spores $/ \mathrm{m}^{3}$ of air established by Gravesen (1979) as the critical value for symptomatology. This result is in agreement with similar variations that have been reported from other temperate regions (Angulo-Romero et al., 1996; Stepalska et al., 1999; Infante et al., 1999a; Filipello Marchisio and Airaudi, 2001; Şakiyan and Inceoğlu, 2003).

The results in the present study are in agreement with other studies in Timisoara. During July 2001, the maximal value of the Alternaria was 339 spores $/ \mathrm{m}^{3}$. Cladosporium conidias were in moderate quantity: 1158 spores $/ \mathrm{m}^{3}$ (Faur et al., 2005). The maximum incidence of Cladosporium spores was noticed in 21 July $2002\left(2252\right.$ conidia $\left./ \mathrm{m}^{3}\right)$. The highest number of Alternaria spores was noticed in 2 July $2002\left(233\right.$ conidia/ $\left.\mathrm{m}^{3}\right)$. In July2002, the air concentration of Alternaria spores exceeded the borderline level of 100 spores $/ \mathrm{m}^{3}$ on 13 days (Ianovici and Faur, 2003). In July 2003, in Timisoara, the maximum value of the total Cladosporium conidia number was recorded on July 5th - 584 conidia $/ \mathrm{m}^{3}$. The maximal value of the Alternaria spores was recorded on July $2-82$ conidia $/ \mathrm{m}^{3}$. Abundant occurrence of Cladosporium spores was noticed from the beginning of July to the end of August (Ianovici et al., 2005). However, the concentrations never exceeded 3000 spores in previous years.

Cladosporium is the fungal genera most correlated with meteorological parameters. This may be attributed to size and nature of conidia (Fig. 2). Cladosporium produces 
24

dry conidia in chains easily carried through air. Therefore dispersion of Cladosporium spores is more influenced by meteorological parameters than Alternaria spores (Awad, 2005).

Daily mean concentrations reflect the approximate numbers of spores found during the day. Half of all episodes of increased pulmonary complaints by asthmatic patients coincided with a total fungal spores peak of more than 500 spores $/ \mathrm{m}^{3}$ of air. The maximum spore concentration was observed on July 5 (1794 spores $/ \mathrm{m}^{3}$ ). In July 2007 , the air concentration of airspores exceeded the bor- spores are found in greatest abundance in the atmosphere characterised by low humidity, generally during warmer afternoon hours (Levetin, 1995).

With regard to spore species, viability can differ considerably, for example, $80 \%$ of Alternaria, and $20-30 \%$ of Cladosporium spores are still viable after a certain period (Govi, 1992). High concentrations and long lasting presence of allergenic fungal spores in the air may cause and intensify clinical symptoms in people suffering from sensitivity and extend the period of presence of allergens in the atmosphere after the flowering season of vascular plants

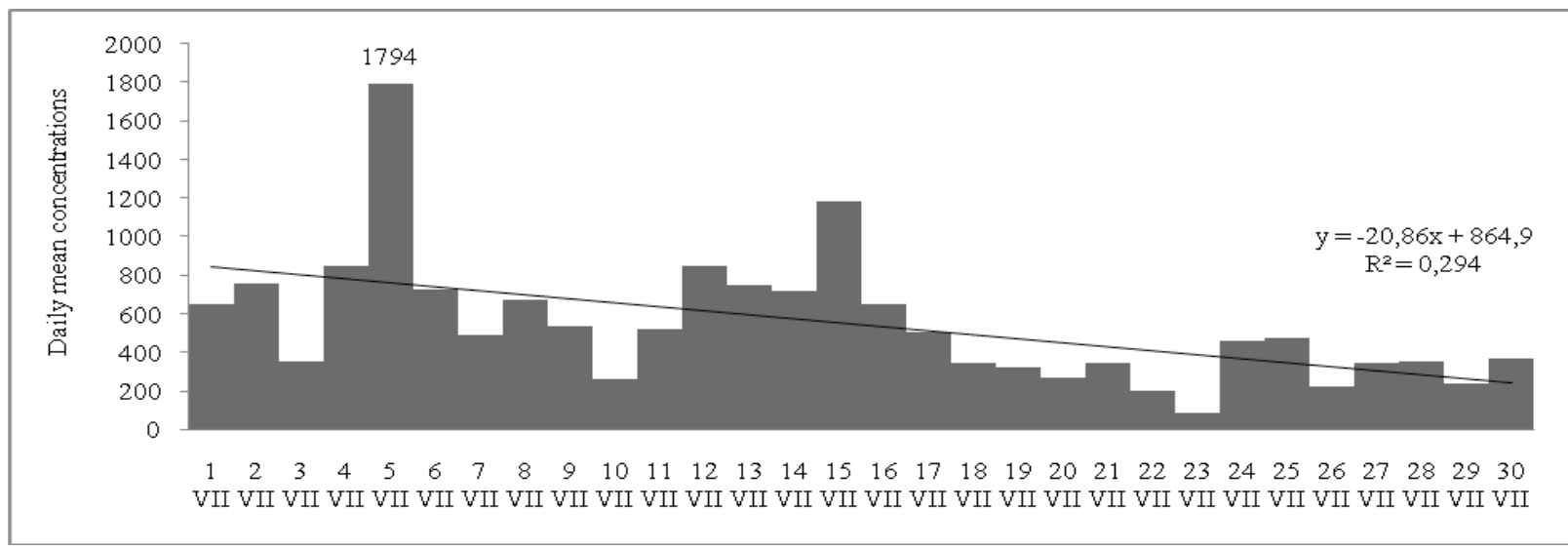

Fig. 1. Totals of spores in the air recorded in Timisoara in July 2007

derline level of 500 spores $/ \mathrm{m}^{3}$ on only 15 days (Fig 1 ).

Liberation of Basidiomycetes and Ascomycetes spores is favoured by high air humidity and rain while Deuteromycetes spores, such as those of Cladosporium and Alternaria, are liberated mechanically by the action of wind on leaves, sometimes aided by water rupture mechanisms activated by drying. Spore dispersal is therefore generally favoured by low relative humidity and increasing temperature. The occurrence of such conditions at different times in different geographical regions may help to explain differences in the observed periodicities (Lacey, 1972; Lacey, 1996).

The distinction between dry-air spores and wet-weather air spores is well known. Dry-air spores include Cladosporium, Alternaria, Epicoccum, Drechslera, Pithomyces and Curvularia (Katial et al., 1997). Members of dry-air

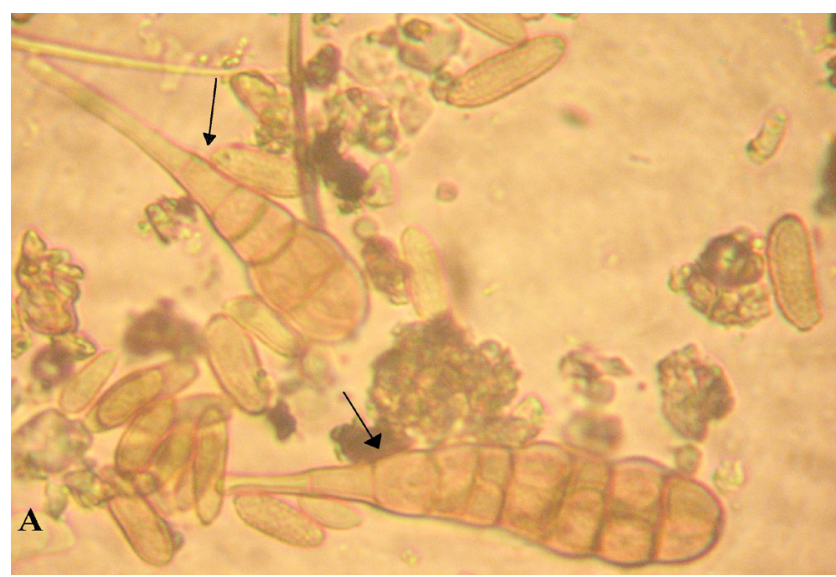

(Stepalska et al., 1999).

Our results show the presence of a large number of fungal spore types. The monitoring of fungal spores in Timisoara revealed the summer as the most favourable season for Cladosporium occurrence. Many surveys of the occurrence of Cladosporium spores in different regions of the world clearly show their dominance in comparison with other spores (Mitakakis et al., 1997). The present study will contribute to our knowledge of airborne spores in Romania.

\section{Conclusions}

Fungal agents are responsible for a variety of respiratory diseases in humans, plants and animals. Aeromycoflora

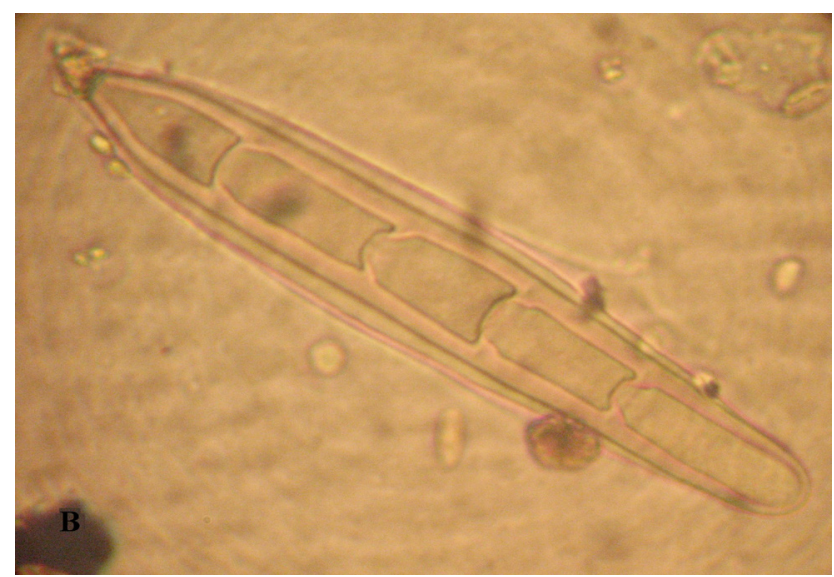



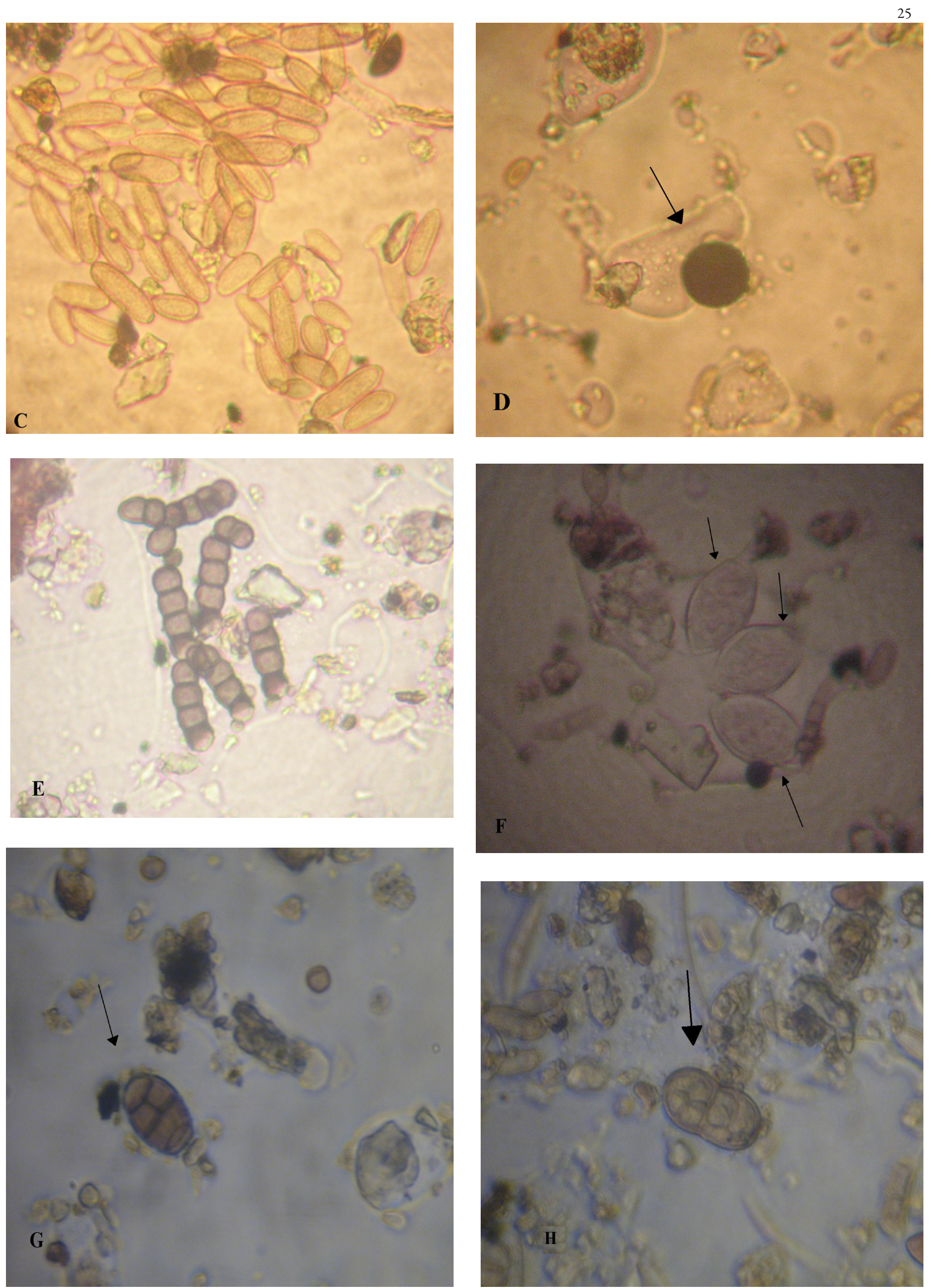

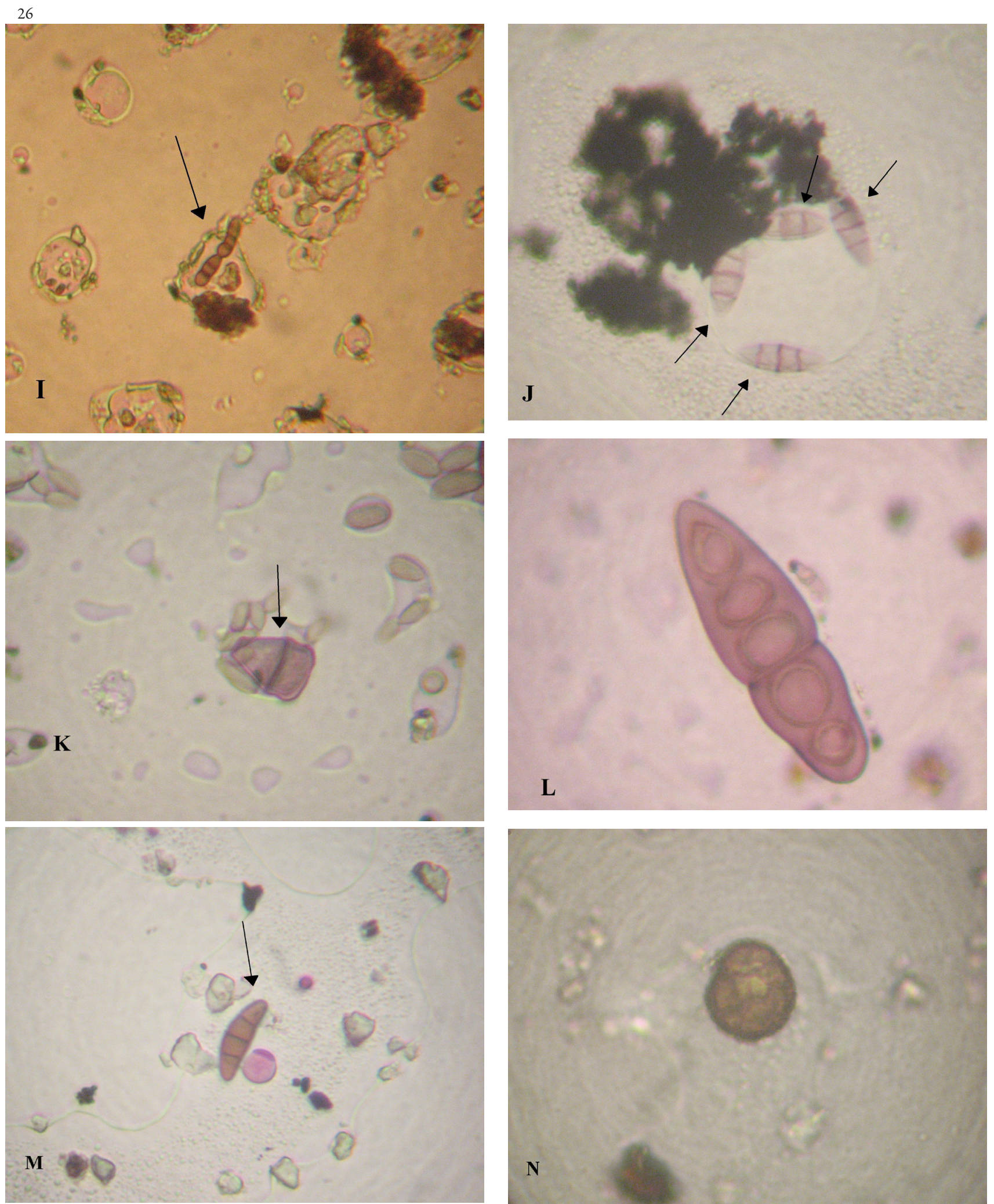

Fig. 2. Airborne fungi detected in Timisoara

(A-Alternaria type; B-Drechslera/Helminthosporium type; C-Cladosporium type; D-Nigrospora type; E-Torula type; FPeronospora type; G-Pithomyces type; H-Stemphylium type; I-Bispora type; J-Capronia type; K-Neohendersonia type; LAmphisphaeria type; M-Fusarium/Leptosphaeria type; N-Epicoccum type) 
of outdoor environment in Timisoara have been investigated. Spores of 32 fungal types were recorded. The spores of Deuteromycetes were the largest contributors of the total airborne fungal spores. Cladosporium was the most prevalent fungal spore type during July 2007 in the air samples from the Timisoara site. Monitoring of airborne fungi can be helpful in prevention of fungal allergic diseases.

\section{Acknowledgments.}

This study has been financed by the City Hall of $\mathrm{Ti}$ misoara, part of the project "Analiza aerobiologică asupra calității aerului prin monitorizarea volumetrică a aeroplanctonului şi aspecte privind impactul plantelor invazive şi alergofitelor asupra biodiversității mediului urban”.

\section{References}

Angulo-Romero, J., F. Infante-García-Pantaleon, E. Dominguez, M. Mediavilla-Molina and J. M. Caridad-Ocerín (1996). Pathogenic and antigenic fungi in school dust of the south of Spain. p. 49-65, In: M. Muilenberg and H. Burge (Eds.). Aerobiology. Lewis Publisher, New York.

Asan, A., S. Burhan and S. Sarica (2002). Airborne fungi in urban air of Edirne city (Turkey). Biologia, 57:59-68.

Awad Abdel Hameed, A. (2005).Vegetation: A source of air fungal biocontaminant, Aerobiologia 21:53-61

Barui Chandra, N. and S. Chanda (2000). Aeromycoflora in the Central Milk Dairy of Calcutta, India, Aerobiologia 16: 367-372.

Burge, H. A. (1985). Fungus allergens. Clin. Rev. Allergy 3: 319-329.

Comtois, P. (1990). Indoor and mold aerosols. Aerobiologia 6: 165-176.

D’Amato, G. and F. Th. M. Spieksma (1995). Aerobiologic and clinical aspects of mould allergy in Europe. Allergy 50:870877.

David, GH., A. Borcean and S. Niță (2008). Grain sorghumperspectives of expanding its cultivation in southern Banat area, Scientific Papers Agriculture, Vol. 40 (1), 63-66.

Faur, A., N., Ianovici and A., Sinitean (2005). Preliminary researches on the incidence of airborne conidia in Timisoara, Annals of West University of Timisoara, ser. Biology, vol. V-VI,11-16

Filipello Marchisio, V. and D. Airaudi (2001). Temporal trends of the airborne fungi and Gravesen S. 1979, Fungi as a cause of allergic disease. Allergy 34:135-154.

Govi, C. (1992). Aerial diffusion of phytopathogenic fungi. Aerobiologia 8:84-93.

Gravesen, S. (1979). Fungi as a cause of allergic disease. Allergy 34:135-154.

Horner, W., E., A. Helbling, J. E. Salvaggio and S. B. Lehrer (1995). Fungal allergens. Clin. Microbiol. Rev. 8:161-179.

Ianovici, N. and A. Faur (2003). Preliminary Study of Some Atmospheric Fungi in Timisoara, The $5^{\text {th }}$
International Symposium "YOUNG PEOPLE AND MULTIDISCIPLINARY RESEARCH”, Section Environmental Protection, 6-7 November 2003, Timisoara, Romania, 624-629

Ianovici, N. (2008). Preliminary survey of airborne fungal spores in urban environment, Scientific Conference "DURABLE AGRICULTURE IN THE CONTEXT OF ENVIRONMENTAL CHANGES", University of Agricultural Sciences and Veterinary Medicine, Faculty of Agriculture, Iasi, 16-18 October 2008, sub tipar

Ianovici, N., A. Daraba, M. Postelnicu, I. Kiss and A. Matis (2007). Study of airborne bio-particles in Timisoara, România, Lucrări Ştiințifice, seria Agronomie, 50(2):501506.

Ianovici, N., A. Faur and A. Rusza (2005). Quantitative and qualitative study on the pneumoallergenic bioparticles during July 2003, Annals of West University of Timisoara, ser. Biology, vol. VII, 25-34

Infante, F., A. Castro, E. Domınguez, A. Guardia, J. Mendez, S. Sabariego and A. Vega (1999b). A comparative study of the incidence of Cladosporium conidia in the atmosphere of five Spanish cities. Polen, 10:15-23.

Infante, F., F. Alba, M. Cano, A. Castro, E. Dominguez, J. Mendez and A. Vega (1999a). A comparative study of the incidence of Alternaria conidia in the atmosphere of five Spanish cities. Polen, 10:5-13.

Kakde, U. B., H. U. Kakde and A. A. Saoji (2001). Seasonal variation of fungal propagules in a fruit market environment, Nagpur (India). Aerobiologia, 17:177-182.

Karlsson-Borga, A., P. Jonsson and W. Rolfsen (1989). Specific IgE antibodies to 16 widespread mold genera in patients with suspected mold allergy. Ann. Allergy 63:521-526.

Katial, R. K., Y. Zhang, R. H. Jones and P. D. Dyer (1997). Atmospheric mold spore counts in relation to meteorological parameters. Int. J. Biometeorol. 41:17-22.

Klironomos, J. N., M. C. Rillig, M. F. Allen, D. R. Zak, K. S. Pregitzer and M. E. Kubiske (1997). Increased levels of airborne fungal spores in response to Populus tremuloides grown under elevated atmospheric $\mathrm{CO}^{2}$. Can. J. Bot., 75: 1670-1673.

Kurup, V. P., B. Banerjee, K. J. Kelly and J. N. Fink (2000). Molecular biology and immunology of fungal allergens, Indian Journal of Clinical Biochemistry, 15(Suppl):31-42

Lacey, J., J. Pepys and T. Cross (1972). Actinomyces and fungus spores in air as respiratory allergens. p. 151, In: D. Shapton and R. Board (eds), Safety in Microbiology, Vol. 6. Soc. Appl. Bact. Techn. Ser.

Levetin, E. (1995). Fungi. p. 87-120, In: Burge HA (Eds). Bioaerosols CRC, Boca Raton.

Mandrioli, P. and A. Zanotti Censoni (1982). L'aerobiologia degli spazi confinati di interesse artistico. Bollettino d'arte, serie speciale, 239-243.

Mircov, V. D., J. Marinkovici and St. Tyr (2007). Climate 
28

characterization during 2005-2006, Scientifical Papers: Agricultural Sciences nr. 39(II):211-214

Mitakakis, T., E. K. Ong, A. Stevens, D. Guest and R. B. Knox (1997). Incidence of Cladosporium, Alternaria and total fungal spores in the atmosphere of Melbourne (Australia) over three years. Aerobiologia 13:83-90.

Pepeljnjak, S. and M. Šegvić Klarić (2003). Occurrence of fungi in air and on plants in vegetation of different climatic regions in Croatia. Aerobiologia, 19:11-19.

Pyrri, I. and E. Kapsanaki-Gotsi (2007). A comparative study on the airborne fungi in Athens, Greece, by viable and nonviable sampling methods, Aerobiologia, 23:3-15.

Saiz-Jimenez, C. (1995). Microbial melanins in stone monuments. Sci. Total Environ. 167:273-286.

Şakiyan, N. and O. Inceoğlu (2003). Atmospheric concentrations of Cladosporium Link and Alternaria Nees spores in Ankara and the effects of meteorological factors. Turkish Journal of Botany, 27:77-81.

Smith, G. E. (1990). Sampling and identifying allergenic pollens and molds. Blewstone Press, San Antonio

Stepalska, D., K. Harmata, I. Kasprzyk, D. Myszkowska and A. Stach (1999). Occurrence of airborne Cladosporium and Alternaria spores in Southern and Central Poland in
1995-1996. Aerobiologia, 15:39-47.

Takahashi, T. (1997). Airborne Fungal ColonyForming Units in Outdoor and Indoor Environments in Yokohama, Japan, Mycopathologia 139:23-33.

Urzi, C., F. De Leo, P. Salamone and G. Criseo (2001). Airborne fungal spores colonising marbles exposed in the terrace of Messina Museum, Sicily, Aerobiologia 17:11-17.

Vijay, H. M., A. J. Thaker, B. Banerjee and V. P. Kurup (1999).

Mold allergens. In: Allergens and Allergen Immunotherapy, Eds. Lockey, R.F. and Bukantz S.C. Marcel Dekker, New York 133-154.

Wu, P. C, H. J Su and C. Y. Lin (2000). Characteristics of indoor and outdoor airborne fungi at suburban and urban homes in two seasons. Sci Total Environ, 253:111-118.

Wuethrich, B. (1989). Epidemiology of allergic diseases: Are they really on the increase. Int. Arch. Allergy Appl. Immunol. 90:3-10.

Zwick, H., W. Popp, S. Jager, C. Wagner, K. Reiser and F. Horak (1991). Pollen sensitization and allergy in children depend on the pollen load. Allergy:46:362-32. 